\title{
Identification of Tomato aspermy virus as the cause of yellow mosaic and flower deformation of chrysanthemums in India
}

\author{
S. K. Raj ${ }^{\mathrm{A}, \mathrm{B}}$, S. Kumar' ${ }^{\mathrm{A}}$ and S. Choudhari ${ }^{\mathrm{A}}$ \\ AMolecular Virology Laboratory, National Botanical Research Institute, Lucknow-226001, India. \\ ${ }^{\mathrm{B}}$ Corresponding author. Email: skraj2@rediffmail.com
}

Abstract. Using indirect ELISA, RT-PCR and coat protein gene sequence analysis, Tomato aspermy virus is identified as the cause of yellow mosaic and flower deformation of Chrysanthemum morifolium cultivars in India.

Chrysanthemum (Chrysanthemum morifolium, family Asteraceae) is a popular ornamental plant worldwide and is one of the most commercially important flower crops in India. Symptoms of yellow mosaic, green vein-banding, stunting and flower deformation were observed on various chrysanthemum cultivars growing in the gardens and nursery of the National Botanical Research Institute, Lucknow, India, between September 2004 and February 2005 (Fig. 1). Cucumber mosaic virus (CMV), Tomato aspermy virus (TAV) and Chrysanthemum virus $B$ (CVB) have previously been reported to infect chrysanthemum (Bouwen and van Zaayen 1995) and, therefore, indirect ELISAs to detect these viruses were performed using the method of Srivastava et al. (1992) and antisera from the American Type Culture Collection. A positive reaction $\left(\mathrm{A}_{405 \mathrm{~nm}}\right.$ four times greater than the healthy chrysanthemum control) was observed with antiserum to TAV (PVSA-24) but not with antiserum to CMV (PVAS 242a) or CVB (PVAS 349).

To prepare template for use in reverse transcriptionpolymerase chain reaction (RT-PCR), total RNA was isolated from healthy and naturally infected leaf tissue of chrysanthemum plants using the method of Spears and Longhurst (1993). Complementary DNA was synthesised using $200 \mathrm{U}$ of RevertAid $\mathrm{H}$-minus MMuLV reverse transcriptase (Fermentas, USA) and the reverse primer 5'-TCACACCGGGAGCGTTGAAGC GGAA- $3^{\prime}$ and PCR performed using 3 U Pfu DNA polymerase
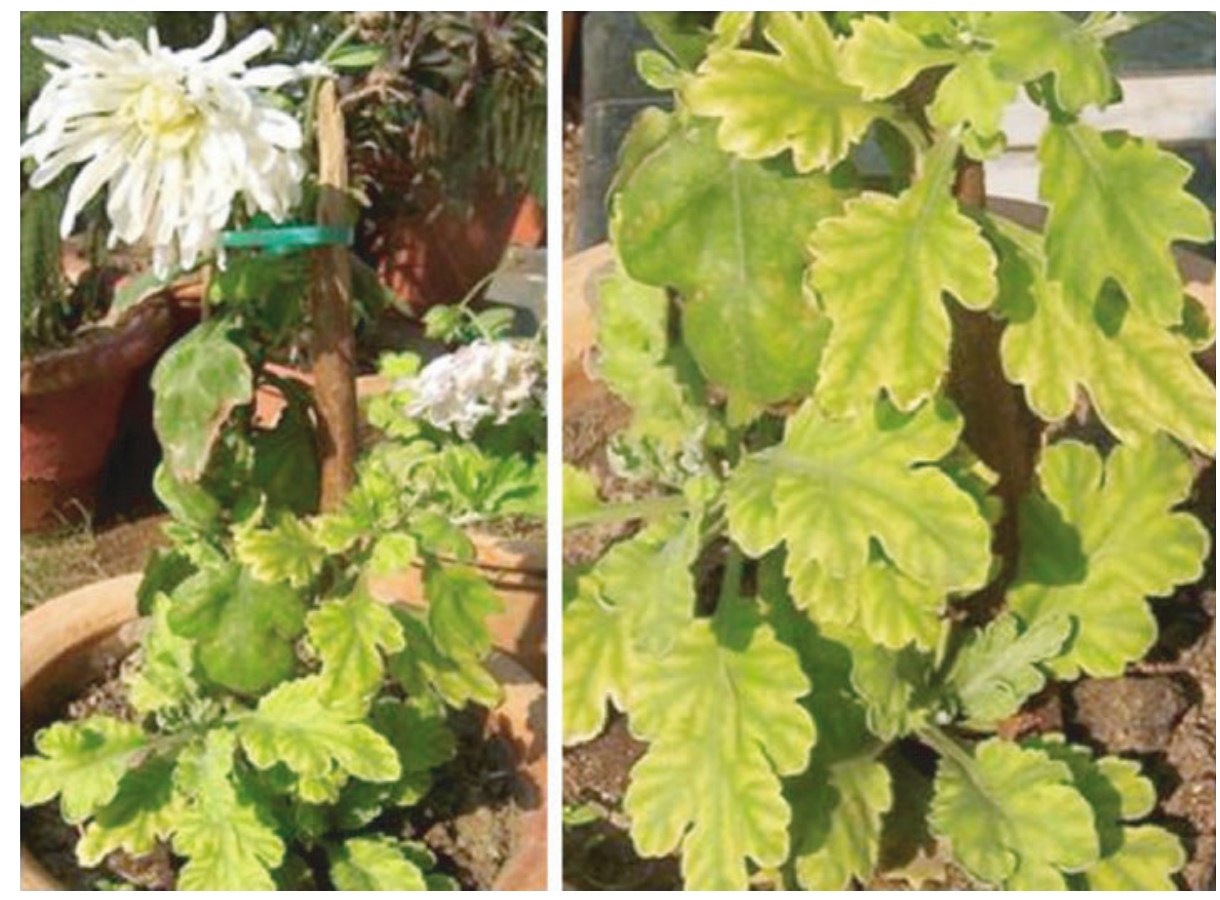

Fig. 1. Chrysanthemum morifolium showing yellow mosaic, stunting and flower deformation. 
Table 1. Coat protein gene-based analysis of the TAV-Lucknow isolate (DQ191798) based on the Genomatix DiAlign programme

\begin{tabular}{lllrc}
\hline $\begin{array}{l}\text { Accession } \\
\text { number }\end{array}$ & Location & Abbreviation & \% Identity based on Genomatix DiAlign \\
used & Nucleotide & Amino acid \\
\hline L79972 & Australia & TAV-V & $97(0.923)$ & $95(0.928)$ \\
L15335 & Hungary & TAV-P & $97(0.923)$ & $95(0.928)$ \\
AJ277269 & USA & TAV-B & $97(0.915)$ & $95(0.928)$ \\
AJ237849 & South Korea & TAV-KC & $97(0.912)$ & $95(0.928)$ \\
AM055753 & New Delhi & TAV-ND & $97(0.918)$ & $94(0.924)$ \\
AM055758 & Haryana & TAV-HR & $97(0.916)$ & $94(0.920)$ \\
AJ580841 & Uttar Pradesh & TAV-UP & $97(0.911)$ & $94(0.924)$ \\
AJ582718 & Punjab & TAV-PJ & $96(0.914)$ & $94(0.925)$ \\
AJ970532 & Sikkim & TAV-SIK & $96(0.897)$ & $93(0.908)$ \\
AJ965491 & Maharastra & TAV-MH & $96(0.888)$ & $93(0.912)$ \\
AM055755 & Karnataka & TAV-KR & $96(0.879)$ & $93(0.906)$ \\
AJ586134 & Himanchal Pradesh & TAV-HP & $95(0.854)$ & $94(0.922)$ \\
AM055757 & Bihar & TAV-BR & $94(0.848)$ & $93(0.899)$ \\
AM055754 & Andhra Pradesh & TAV-AP & $92(0.840)$ & $94(0.920)$ \\
AJ965492 & TamilNadu & TAV-TN & $93(0.830)$ & $94(0.913)$ \\
AM049404 & Assam & TAV-Asm & $94(0.833)$ & $91(0.870)$ \\
AM049403 & Arunanchal Pradesh & TAV-ArP & $94(0.818)$ & $93(0.895)$ \\
AM055756 & Madhya Pradesh & TAV-MP & $93(0.810)$ & $88(0.822)$ \\
AM055591 & Gujarat & TAV-GR & $90(0.749)$ & $86(0.793)$ \\
AM055592 & Uttaranchal & TAV-UT & $89(0.710)$ & $84(0.785)$ \\
\hline
\end{tabular}

${ }^{\mathrm{A}}$ The \% identity denotes number of identical sequences (in \% of shorter sequence) and value given in brackets is the similarity (relative to the maximum similarity).

(MBI Fermentas, USA) using the same reverse primer combined with the forward primer 5'-ATGGCCCAAAACGG TACGGGAGGAG-3'; reactions were set up as described in the manufacturer's instructions. An amplicon of the expected size ( $\sim 650 \mathrm{bp}$ ) was obtained, which was cloned using the pGEM-T Easy vector system (Promega, USA). Sequencing was conducted at Genei (Bangalore Genei Pvt. Ltd, India) and the sequence submitted to GenBank (Accession number DQ191798). When analysed using the DiAlign 2 module of GEMS Launcher (Genomatix), DQ191798 was 97\% identical at the nucleotide level and $95 \%$ at amino acid level with seven other TAV isolates from India and elsewhere in the world (Table 1).

We therefore conclude that the cause of the yellow mosaic and flower deformation in the chrysanthemums was TAV. The occurrence of TAV in chrysanthemum in India has been reported previously on the basis of biophysical properties, aphid transmissibility and Ouchterlony gel double diffusion tests (Sastry 1964; Gupta and Singh 1981; Raj et al. 1991). However, to the best of our knowledge this is the first report of the molecular characterisation of a TAV isolate infecting chrysanthemums in India.

\section{Acknowledgements}

The authors express gratitude to the Director, NBRI, Lucknow for facilities; Dr S. K. Dutta, head, Floriculture for providing infected samples of chrysanthemum; Department of Science and Technology (DST), New Delhi for financial support and Council of Scientific and Industrial Research (CSIR), New Delhi for fellowship to S. Kumar.

\section{References}

Bouwen I, van Zaayen AZ (1995) Chrysanthemum. In 'Virus and virus like disease of bulb and flower crops'. (Eds G Loebenstein, RH Lawson, AA Brunt) pp. 396-408. (Willey Publications: Chichester, UK)

Gupta RP, Singh BP (1981) Studies on Chrysanthemum aspermy virus on Chrysanthemum. Indian Journal of Mycology and Pathology 11, 158-160.

Raj SK, Srivastava KM, Raizada RK, Singh BP (1991) Chlorotic ring mosaic of chrysanthemum caused by a strain of Chrysanthemum aspermy virus in India. Journal of Plant Disease and Protection 98, 640-646.

Sastry KSM (1964) A new strain of CAV from India. Indian Journal of Microbiology 4, 37-40.

Spears J, Longhurst T (1993) RNA extraction and fractionation. In 'Methods in Plant Biochemistry, Vol. 10'. (Eds PM Dey, JM Harbome) pp. 1-33. (Academic Press: New York)

Srivastava KM, Raj SK, Singh BP (1992) Properties of a Cucumber mosaic virus strain spontaneously infecting Chrysanthemum in India. Plant Disease 76, 474-477.

Manuscript received 20 July 2006, accepted 29 November 2006 